Hydrogeology Journal, 2006, 14(5), 637-647. DOI 10.1007/s10040-005-0467-0

\title{
Climate change impacts on groundwater recharge- uncertainty, shortcomings and the way forward?
}

I.P. Holman

Institute of Water and Environment, Cranfield University, Silsoe, Bedford MK45 4DT, United Kingdom

Tel: $\quad+44(0) 1525863000$

Fax: $\quad+44(0) 1525863344$

Email: i.holman@cranfield.ac.uk

\begin{abstract}
An integrated approach to assessing the regional impacts of climate and socioeconomic change on groundwater recharge is described from East Anglia, UK. Many factors affect future groundwater recharge including changed precipitation and temperature regimes, coastal flooding, urbanization, woodland establishment, and changes in cropping and rotations.
\end{abstract}

Important sources of uncertainty and shortcomings in recharge estimation are discussed in the light of the results. The uncertainty in, and importance of, socio-economic scenarios in exploring the consequences of unknown futures are highlighted. Changes to soil properties are occurring over a range of time scales, such that the soils of the future may not have the 
same infiltration properties as existing soils. The potential implications involved in assuming unchanging soil properties are described.

To focus on the direct impacts of climate change is to neglect the potentially important role of policy, societal values and economic processes in shaping the landscape above aquifers. If the likely consequences of future changes of groundwater recharge, resulting from both climate and socio-economic change, are to be assessed, hydrogeologists must increasingly work with researchers from other disciplines, such as socio-economists, agricultural modellers and soil scientists.

Keywords Groundwater recharge, Climate change, Socio-economic aspects, Numerical modelling, Groundwater management

\section{Introduction}

The potential impacts of climate change on water resources have long been recognised, although there has been comparatively little research relating to groundwater (IPCC 2001). The principle focus of climate change research with regard to groundwater has been on quantifying the likely direct impacts of changing precipitation and temperature patterns (e.g. Yusoff et al. 2002; Loaiciga et al. 2000; Arnell 1998). Such studies have used a range of modelling techniques such as soil water balance models (e.g. Kruger et al. 2001; Arnell 1998), empirical models (e.g. Chen et al. 2002), conceptual models (e.g. Cooper et al. 1995) and more complex distributed models (e.g. Croley and Luukkonen 2003; Kirshen 2002; Yusoff et al. 2002), but all have derived changes in groundwater recharge assuming parameters other than precipitation and temperature remain constant. 
Studies which have gone further than this, in considering the indirect effects derived from climate change-induced alterations in soil (Feddema and Freire, 2001), landcover (Loukas et al. 2002), salt-water intrusion due to rising sea levels (Bobba 2002; Sherif and Singh 1999) and changes in water demand (Alderwish and Al-Eryani 1999; Meigh et al. 1999; Chen et al. 2001) are less common. These studies represent a move away from impact studies (which may be considered to be vertically integrated, in which climate change acts upon an environmental compartment) towards horizontally integrated studies in which environmental compartments interact with each other . However, they remain an incomplete assessment of the pressures facing groundwater resources associated with the direct and indirect effects of future climate and socio-economic change.

Current European Commission legislation, such as the Water Framework Directive and Nitrate Directive in Europe, increasingly recognises that groundwater cannot be considered in isolation from the landscape above, the society with which it 'interacts', or from the regional hydrological cycle, but needs to be managed holistically. In understanding the likely consequences of possible future (climate and non-climate) changes on groundwater systems and the regional hydrological cycle, an important (but not exclusive) component to understand is the influence that these factors exert on recharge and runoff. This paper describes an approach towards estimating groundwater recharge which takes into account the direct and indirect contributions of climate change and socio-economic change, and further considers the uncertainties and potential shortcomings which are pertinent for future recharge assessment and groundwater modelling studies. 


\section{Methodology}

The 'Regional Climate Change Impact and Response Studies in East Anglia and North West England' (RegIS) (Holman et al. 2005a In Press) developed a research methodology for stakeholder-led, regional climate change impact assessment that explicitly evaluated local and regional (sub-national) scale climate change impacts and adaptation options, and crosssectoral interactions between the major 'sectors' driving landscape change (coastal, agricultural, water and biodiversity sectors).

Of the numerous Integrated Assessment frameworks available (e.g. Argent 2004), the 'Drivers-Pressure-State-Impact-Response' (DPSIR) approach (European Environment Agency 1998) was chosen, the components of which were used to define the various stages of the RegIS methodology:

D: Drivers are the underlying exogenous (to the region) causes of environmental change, e.g. climate and socio-economic change, national and international policy. They are described by qualitative narratives or storylines.

P: $\quad$ Pressures are the endogenous (to the region) variables that quantify the drivers, e.g. temperature, precipitation etc. for climate change; and population, subsidies etc. for socio-economic change. These are applied through regional, quantitative scenarios.

S: $\quad$ States are the variables (indicators) that represent the sensitivity of the system to the pressure variables, e.g. groundwater resources, river flows, land use areas. Coupled, sectoral models simulate indicators of sectoral impacts and cross-sectoral interactions.

I: Impacts are a measure of whether the State variables have reached a certain value (represented by thresholds etc.), which has a negative or positive effect e.g. minimum 
groundwater levels or river flows, acceptable farm profit etc. These are quantified by applying critical thresholds to the outputs from the linked models.

R: Responses are the planned (societal level) adaptation options that aim to minimise negative impacts (or maximise positive impacts / benefits). These are identified with stakeholders and evaluated with linked models and expert knowledge.

The RegIS methodology is described elsewhere (Holman et al. 2005a In Press) but, in the context of groundwater recharge, is summarized below:

1. The modelling context is provided by the climate and socio-economic scenarios;

2. Relevant spatial and non-spatial data, including data from (1) are extracted from a GIS;

3. Using data from (2), the coastal and river modelling determines areas not suitable for agriculture on the basis of flood frequency estimation;

4. Output from (3) and urban, upland and woodland areas from (2) exclude areas from which the agricultural modelling can determine the land use distribution of arable and grassland systems;

5. The land use distribution is based on profitability, arising from costs, prices and subsidies (from the socio-economic scenarios) and predicted yields for each crop-soil type combination- the latter from a crop-growth model which includes a full soil-water balance;

6. The output data of hydrologically effective rainfall from (5) provides the input to the hydrological modelling, which simulates potential recharge, gross groundwater resources (for areas underlain by aquifers) and river flows.

\section{The input scenarios}


Climate change scenarios have been developed on behalf of the United Kingdom Climate Impacts Programme (UKCIP), known as the UKCIP98 scenarios (Hulme and Jenkins 1998), using output from the HadCM2 General Circulation Model. A high and a low climate change scenario for the period 2040-2069, termed the 2050s Low and 2050s High scenarios, were used to characterise the lower and upper ends of the expected temperature changes.

As the future world will change even without climate change, regional socio-economic scenarios were derived (Shackley and Deanwood 2003). In addition to storylines, these scenarios contain a range of quantified spatial (Figure 1) and non-spatial model parameters.

Internally consistent futures were modelled, in which the assumptions which underpin the different scenarios (socio-economic, $\mathrm{CO}_{2}$ emission and climate change) are consistent:

- Regional Enterprise (equivalent to the IPCC A2 emissions scenario) socio-economic scenario linked with the 2050s High climate change scenario. This future provides an extreme case of a society that does not respond to the threat of climate change over the next 50 years i.e. an 'adverse case' analysis;

- Global Sustainability (equivalent to IPCC B1 emissions scenario) socio-economic scenario linked with the 2050s Low climate change scenario, represents a 'better case' analysis with respect to pressures upon environmental systems and associated impacts.

In addition, the linked models were run for the two climate change scenarios with baseline (current) socio-economics scenario to assess the relative importance of climate change and socio-economic change.

\section{Impact modelling}


Regional heterogeneity is accommodated by applying a spatial modelling approach to a geographic grid of $5 \mathrm{~km} \times 5 \mathrm{~km}$. Although model outputs were aggregated to the $5 \mathrm{~km}$ grid, the models were applied to smaller geographical units within each grid cell, such as floodplains, soil types, cultivatable land etc. A range of validated impact models were linked within the RegIS methodology (Holman et al. 2005a In Press), which are briefly described below.

\section{Coastal and river flooding}

The coastal and river flooding model (Nicholls and Wilson 2001) assessed the impact of increased flooding on the agricultural sector. The effect of sea level rise on tide-surge heights was estimated by adding the UKCIP98 sea level rise projections to the water levels of specific return periods as no data are provided for other climatic factors such as storminess.

Floodplains where the future standard of defence (i.e. risk of flooding) will be less than 1 in 10 years were assumed to be unsuitable for arable farming, while those with a future standard of less than 1 in 1 year were assumed to be unsuitable for both arable and pastoral farming.

\section{Agricultural land use modelling}

The agricultural land use modelling integrates an optimisation approach to farm level cropping decisions (SFARMOD) with a crop growth model (ACCESS). The approach and validation are described in Rounsevell et al. (2003). Farms within SFARMOD optimise their long term farm cropping plan on each soil type within each grid cell by maximising farm profit, in response to changes in the profitability/feasibility of enterprises, soil workability and simulated yields brought about by changes in climate and / or socio-economic conditions.

\section{Water resources modelling}


The distributed semi-empirical SWANCATCH (Surface WAter Nitrate CATCHment) model (Holman et al. 2001) was used to simulate naturalised surface water flows ${ }^{1}$ in 88 catchments/sub-catchments and gross groundwater resources in 51 water management units. SWANCATCH routes the hydrologically effective rainfall (that proportion of the rainfall which is able to run off or infiltrate the surface) from the land use modelling through each soil type directly to surface water or to a groundwater store ${ }^{2}$, according to the Hydrology Of Soil Types (HOST) system (Boorman et al, 1995).

HOST is a conceptual representation of the hydrological processes in the soil zone. All soil types in the United Kingdom have been grouped into one of 29 hydrological response models (or HOST classes), for which calibrated values of Base Flow Index (BFI) and Standard Percentage Runoff (SPR) are given. BFI is the long-term average proportion of flow that comes from groundwater stores and SPR is the percentage runoff derived from measurements of runoff events, adjusted to standard rainfall and catchment moisture conditions (Boorman et al., 1995). The HOST classification is capable of predicting river flows in ungauged catchments throughout the UK $\left(r^{2}=0.79\right.$, standard error of estimate of 0.089 in the case of Base Flow Index).

The paucity of data on distributed groundwater recharge or naturalised river flows makes the validation of such regional studies difficult. SWANCATCH was regionally calibrated against long-term average annual gross groundwater resource estimates for the water management units $\left(\mathrm{r}^{2}=0.97\right)$; and validated by comparison of simulated and observed $95^{\text {th }}$ percentile and $50^{\text {th }}$ percentile exceedence river flows from nine catchments $\left(r^{2}=0.92\right.$ and 0.99 , respectively).

\footnotetext{
${ }^{1}$ Flows which have had the abstractions added back in and the discharges removed.

${ }^{2}$ The groundwater store in the model provides baseflow to the river. It may, but does not have to, meet the definition of an aquifer, of yielding significant quantities of water to wells and springs.
} 


\section{Case study results in the context of groundwater recharge impacts}

The case study described was performed in East Anglia (Fig. 2), the flattest part of the UK, with appreciable areas such as the Fens below sea level. The climate is influenced by its low relief and proximity to the continent, with average annual rainfall of $550-750 \mathrm{~mm}$, and agriculture is characterised by intensive arable cultivation. The region is largely (with the exception of the Fens) underlain by Cretaceous (chalk and greensand) or Pleistocene (crag) aquifers. As such it is highly dependent on groundwater, which provides much of the public water supply and irrigation needs and supports river flows and internationally important wetland areas such as The Broads. The area has a relatively low level of urbanization, with the exception of key centres such as Cambridge and Norwich.

\section{$\underline{\text { Coasts }}$}

Climate change may have profound implications for coastal areas and river valleys in East Anglia. Without adaptation (or existing allowances for future sea-level rise in flood defence guidance), the interaction of sea-level rise, increased river floods and land subsidence (due to regional isostatic adjustment and local peat oxidation) could lead to severe flood impacts in the Fens of East Anglia, leading to large-scale abandonment and salinization (Fig. 3). Large areas of the river valleys in east Norfolk would also experience regular sea water inundation. It took up to five years for grazing marshes in east Norfolk to fully recover from the 1938 floods, so it is probable that a frequency of coastal flooding of even 1 in 10 years would lead to major land use change. Unlike the Fens which are underlain by Jurassic clays, the river valleys in east Norfolk overlie the Crag aquifer, a locally important unconsolidated aquifer (Holman et al., 1999). Regular inundation by seawater would lead to the probable abandonment or relocation of boreholes in, or close to, these river valleys. 


\section{$\underline{\text { Agriculture }}$}

Cropping distribution in East Anglia is relatively insensitive to climate, changing little between the present climate and the future climate change scenarios (under the baseline socioeconomic scenario) apart from areas prone to flooding. However, cropping patterns are very sensitive to the socio-economic scenarios (Fig. 4). Spring-sown crops gain over autumn-sown crops in East Anglia, with particular increases in irrigated sugar beets and potatoes. For the prices in the socio-economic scenarios, the results suggest that the area of irrigated potatoes would double with resulting increases in groundwater abstraction, despite large increases in the water price.

\section{$\underline{\text { Saline intrusion into aquifers }}$}

Saline intrusion into coastal aquifers is considered not to be a major problem, as sea level rises should necessitate only minor reductions in so-called safe yield abstraction rates, or the movement of boreholes inland (Arnell et al. 1994). However, land drainage changes in some of the coastal marshes in east Norfolk, in response to land abandonment (Fig. 3) or agricultural policy change, may induce increased saline intrusion within the Crag aquifer (Holman and Hiscock 1998).

\section{Hydrologically Effective Rainfall (HER)}

The warmer future climate leads to an increase in the length of the growing season, so that the region's soils return to field capacity later in the autumn and start drying out sooner in the spring. This leads to a reduction in the length of the recharge period as shown in Fig. 5. The overall effect is to reduce Hydrologically Effective Rainfall, and consequently recharge, in much of the region, even though annual rainfall increases. Fig. 6 shows the seasonal contribution to the change in average annual HER between the Baseline and 2050s High, with 
the grid cells ordered by decreasing percentage change of average annual HER. The bulk of the change in annual average HER is caused by a decrease in autumn HER and also winter HER due to increased actual evapotranspiration.

The socio-economic scenarios affect the average annual HER predictions at the local and regional scales as shown in Fig. 7. Locally, increased urbanisation and woodland establishment lead to significant changes in evapotranspiration and HER. The socioeconomic scenarios can also cause regional changes in land use, such as an increase in the cultivation of spring-sown crops at the expense of autumn-sown crops under the Regional Enterprise scenario, which results in a small regional increase in average annual HER.

\section{Feedback effects}

As the first attempt to produce an integrated assessment of climate and socio-economic change, the RegIS study was inevitably an incomplete representation of the complex mechanisms controlling landscape change. In particular a number of limitations of the study are:

- The degree of actual flooding will be dependent on society's response to sea level rise and storminess, which might take the form of raised sea defences and river levees or more sustainable measures such as managed realignment (an engineering process involving the physical removal or deliberate breaching of existing flood defences in order to re-establish intertidal habitat and enhance natural flood defences);

- No feedbacks were implemented between abstraction and water resource availability or critical thresholds of surface water flows / groundwater levels. Although irrigation use was limited by profitability, rotation and cultivation constraints (i.e. potatoes could only be grown on up to $25 \%$ of suitable soils because of a 1-in-4 year rotation), the 
actual availability of irrigation water was assumed to be unconstrained. An increase in water price was used to represent the increased costs of on-farm water storage (as opposed to direct abstraction), but it is likely that the agricultural sector will face increased water resource constraints (Weatherhead and Knox 1999);

- Similar limitations apply to the scenarios of urban development, which assumed that the increased population and housing were unconstrained by water availability;

- There was no agricultural supply-demand price feedback on the agricultural crops, as it was assumed that the regional supply did not affect the market commodity price.

- Internally consistent futures in which the assumptions in the different scenarios (socioeconomic, $\mathrm{CO}_{2}$ emission and climate change) are consistent, implicitly assumes that regional and global societies are developing along similar pathways.

\section{Discussion}

Although assessments of potential groundwater recharge in East Anglia were derived (Holman et al. 2005b In Press), they are not presented here. Instead, the presentation of results concluded with the derivation of Hydrologically Effective Rainfall, that portion of rainfall which is available for recharge or runoff depending on landscape conditions. This is because the most significant issues in assessing the impacts of future (climate and socioeconomic) change on groundwater recharge are associated with:

1. uncertainties in calculating HER; and

2. shortcomings in the implicit assumptions for partitioning HER into recharge and runoff.

\section{Sources of uncertainty}

\section{Socio-economic input scenarios}


Integrated assessment allows the assessment of the impacts of future change on the water environment. In particular, the successful integration of socio-economic scenarios into the modelling of spatial land use enables the indirect impacts, resulting from changing patterns of urbanization, flooding and cropping, to be assessed and quantified.

The direct impacts of the climate scenarios on hydrologically effective rainfall are generally regionally more important than those of the socio-economic scenarios. However, the socioeconomic scenarios do cause regional changes in HER and locally their impacts can be highly significant, especially where there are major land use changes. Because simulated land use distribution is derived from a model in which farmers are maximising farm profit, the results are sensitive to the elements of the socio-economic scenarios which affect the profitability of individual crops either directly (e.g subsidies, prices etc.) or indirectly (labour, input prices etc.). Similarly the changing patterns of urbanization are dependent upon the scenarios of population change, housing density and household size.

Clearly in both cases, all of these parameters are uncertain, even though they are developed within the constraints of the future defined by the scenario. Although scenario development is an imperfect 'science' (Parson and Granger Morgan 2000), few alternatives exist in exploring the consequences of unknown futures. Scenarios are therefore an integral part of climate impact assessment (Leemans 1999) and will continue to be widely used by the scientific and policy-making communities.

\section{Scenario (adaptation) feedbacks}

One of the principal limitations of scenarios results from feedbacks across scale boundaries, such as the effect of changing land use areas on agricultural prices: increasing the local 
supply of an individual crop may result in lower prices dependent upon market demand and supply. These types of dynamic cross-scale processes cannot be dealt with in a satisfactory way using a scenario approach, and alternative approaches (e.g. Cash and Moser 2000) that can operate across scales such as hierarchy theory or nested models that operate at different scales may be needed (Easterling 1997). Studies have attempted to model the price change feedback that results from agricultural land use change using a model of macro (global) economics that simulates all regions of the world (e.g. Parry et al. 1996; Conway et al. 1996).

Hydrogeologists are used to high-resolution, site-scale groundwater models being nested within basin-scale models, in order for simulated boundary conditions or fluxes to be applied to the 'inner' model (e.g. Keating et al. 2003). However, there is a need for groundwater models to be coupled to nested land use / landscape models if the implications of these feedback mechanisms on land use and recharge are to be fully incorporated.

\section{Mitigation (response) scenarios}

Mitigation scenarios can also introduce uncertainty into the assessment of the indirect impacts of climate change on groundwater. For example, conversion of arable land to energy or biomass crop production (e.g Miscanthus and Short Rotation Coppice for willow- Salix spp. and poplar- Populus spp.) is a potential means of carbon sequestration and fossil fuel replacement. However, while Kort et al. (1998) stress the advantages associated with improved soil organic matter, soil structure and water infiltration, Stephens et al. (2001) highlight the significantly increased soil water use by these crops, which would lead to reduced recharge.

\section{Temporal and spatial scale}


For groundwater recharge estimation, changes in precipitation amount and intensity (insofar as it affects runoff and infiltration) are much more important than changes in temperature. Many studies suggest that precipitation intensities will tend to increase, particularly for larger events (e.g. Voss et al. 2002; Jones and Reed 2001). However, although the issues of, and approaches to, downscaling the results from Global Climate Models (GCMs) or Regional Climate Models to a scale relevant for hydrological impact studies are well known, and are reviewed by Prudhomme et al. (2002), there is no single appropriate downscaling approach.

A spatial modelling scale is also needed that balances the data, model run-time and credibility constraints that result from an integrated, multi-sectoral modelling approach against the spatial resolution desired by hydrogeologists (of the order $0.5 \times 0.5 \mathrm{~km}$ or $1 \mathrm{~km} \mathrm{x} 1 \mathrm{~km}$ ). Climate change scenarios are typically at a coarser resolution- the $10 \mathrm{~km} \times 10 \mathrm{~km}$ resolution of the UKCIP98 scenarios was derived using 'unintelligent downscaling' (Hulme and Jenkins 1998) which added no new meteorological insight beyond the GCM-based changes, and hence implicitly limits the credibility of much further downscaling. The newer UKCIP02 climate scenarios were generated using a nested higher resolution Regional Climate Model within the GCM, but this has only allowed $5 \mathrm{~km} \times 5 \mathrm{~km}$ output. There are similar, but greater, issues of credibility with downscaling the spatial components of the socio-economic scenarios.

Recharge models of any spatial scale can, in theory, be embedded within such an integrated assessment. However, there are fundamental spatial limits to the resolution of climate and socio-economic scenarios, and to other spatial models e.g. land use, which means that spatial input parameters to a recharge model are not resolved at that detailed scale. 


\section{$\underline{\text { Shortcomings }}$}

The analysis presented in this paper has assumed, in common with almost all assessments of climate change impacts, that the physical properties of the landscape (other than those changed fundamentally by urbanization) remain constant. Typically, available soil property data (such as bulk density, water retention and hydraulic conductivity), which have been collected over a number of past years by soil survey organizations, are used to parameterise the simulation of infiltration / runoff / soil water availability. Once calibrated, the model is then used predictively, with the soil properties unchanged. However, there is mounting evidence that the condition of temperate soils are changing at a range of temporal scales (Rounsevell et al. 1999), and this has concomitant implications for assessments of future groundwater recharge.

\section{Short term changes}

A range of cropping and stock management systems in intensive agriculture have the potential to significantly modify soil hydrology (e.g. Chambers and Garwood 2000), by impacting upon soil structural conditions. These impacts mainly result from the need for machinery or livestock to access land at times when soils are at, or approaching, their wettest season. A study in four contrasting UK catchments in 2000 showed widespread soil structural degradation, for which an initial assessment of the resulting hydrological impacts suggested significantly increased runoff (Holman et al. 2003), and consequent decreases in recharge.

Climate change will cause a change in the timing of the return of soils to their field capacity state. If it occurs later in the autumn, as in Figs. 5 and 6, an increase in the length of the autumn cultivation period may reduce the likelihood of needing machinery to access land when it is wet. However, the scope provided by climate change to introduce new crops (e.g 
sunflowers- Harrison and Butterfield 1996; grain maize- Carter et al. 1992; forage maizeDavies et al. 1996) and to alter current rotations (e.g. Bowman et al. 2000) means that the potential to impact on soil conditions should not be discounted. Land use models which incorporate workability restrictions due to soil wetness conditions should be used to assess the implications of the introduction of novel crops or altered rotations on groundwater recharge.

\section{Medium term changes}

The potential for intensive agricultural systems to decrease in soil organic carbon (SOC) concentrations is widely recognised (Reeves 1997). Studies in different soils and climatic conditions (e.g. Cannell and Hawes 1994, Hernanz et al. 2002), have demonstrated a positive correlation between SOC and structural stability of soil aggregates, enabling them to withstand wetting and mechanical forces due to tillage implements and vehicular traffic (Tisdall and Oades 1982). Loveland and Webb (2003) state that although there is little quantitative data to substantiate it, it seems widely believed that a major 'critical' SOC threshold is at $2 \%$ SOC (ca. $3.4 \%$ soil organic matter), below which a potentially serious decline in soil quality will occur. Future or continuing decreases in SOC (e.g. as described by Webb et al., 2001) associated with changes in cropping or rotations (e.g. Bowman et al. 2000) or increases in soil erosion (e.g. Pruski and Nearing 2002) may therefore be of concern for infiltration and recharge studies.

Crop changes can introduce changes to carbon cycling. For example, rotations containing sunflowers led to lower SOC content in the upper topsoil, attributed to increased tillage and the lower amounts of residue incorporation (Bowman et al. 2000). Even if cropping patterns and rotations remain constant, the effects of different tillage practices, such as conventional tillage, reduced tillage and no-till systems on surface sealing, aggregate stability (Tebrugge 
and During 1999) and water movement (e.g. O’Leary 1996; Ankeny et al. 1995) are becoming increasingly understood

\section{Longer term changes}

Peat soils are important for regulating catchment hydrological response (e.g Bragg 2002), but are vulnerable to extraction, burning or drainage. Once drained, agricultural peat soils are prone to wastage of 1-2 $\mathrm{cm} \mathrm{a}^{-1}$ (Cannell et al. 1999) due to consolidation and oxidation. While peat soils tend not to overlie important aquifers or are located in an aquifer's discharge zone, the environmental function of groundwater within them is important, in regulating the flow of water in downstream rivers. If an integrated surface water - groundwater model in a catchment with significant peat soils is calibrated and then applied predictively without considering potential changes in the peat, it may overestimate future baseflow contribution.

\section{When is an Integrated view merited?}

The RegIS Integrated Assessment methodology has (partially) demonstrated how an holistic view of the consequences of future change on groundwater recharge, and therefore groundwater resources, can be assessed. However, to fully implement such an approach is a complex and resource-intensive exercise. It is relevant therefore to consider when simpler (e.g. climate-only) assessment approaches are appropriate.

The significance of a change in hydrologically effective rainfall or recharge needs to be assessed within the context of exploitable groundwater resources (Quinn et al. 2004), and the impacts of any change for the aquatic environment (Sophocleous 2002; Baron et al. 2002; Danielopol et al., 2003) or for future groundwater quality (e.g. Gomez et al 2003). In light of 
the result that climate change has the larger impact on HER regionally, but that socioeconomic-induced changes can have a dramatic impact locally, it is suggested to use:

- Simple direct estimations of climate-change-only impacts on groundwater (assuming current land use distributions) in areas where:

$\circ$ current groundwater resource management is sustainable, and there are significant unutilized resources;

- there are few groundwater-sensitive wetlands or aquatic systems;

○ such estimations demonstrate only minor impacts on groundwater recharge and sustainable water resource management, which is supported by sensitivity analysis.

- Partially integrated assessments in areas where:

- current groundwater resource management is sustainable, but there is little unutilized resources;

$\circ$ agricultural systems are prone to significant change, either short-term due to changes in subsidies or environmental legislation; or longer term due to climate change-induced changes in crop suitability;

- spatial development planning pressures suggest significant possible increases in urban development;

- land use and groundwater recharge quality may be sensitive to future coastal defence policy.

- Fully integrated assessments in areas where:

- current groundwater resource management is unsustainable; or 
$\circ$ there are important groundwater-sensitive wetlands or aquatic systems and current groundwater resource management is sustainable but there is little unutilized resources.

Due to a lack of data or knowledge as to the magnitude and extent of such future changes, it may not be possible to include all of these effects quantitatively in groundwater recharge modelling. However, to ensure that groundwater studies are robust to these sources of uncertainty, it is important that:

- hydrogeologists should increasingly work in interdisciplinary teams to improve the representation or appreciation of these processes within groundwater modelling;

- the potential effects on recharge and groundwater systems are assessed through comprehensive sensitivity analyses.

\section{Conclusions}

This paper has described an integrated approach to assessing the direct and indirect impacts of climate and socio-economic change on groundwater recharge, which has been applied in a case study in East Anglia, UK. Many factors will affect groundwater recharge including changed precipitation and temperature regimes, coastal flooding, urbanization and surface sealing, woodland creation, cropping and rotation changes. The direct impacts of the climate scenarios are generally regionally more important than those of the socio-economic scenarios. However, the socio-economic scenarios do cause regional changes and locally, the impacts of the socio-economic scenarios can be highly significant, especially where they lead to major land use changes. 
The importance of socio-economic scenarios in exploring the consequences of unknown futures has been highlighted. However, despite the many uncertainties involved in the use of scenarios, to solely focus on the direct impacts of climate change (arising from temperature and precipitation changes) is to neglect the potentially important role of societal values and economic processes in shaping the landscape above aquifers. There are also changes occurring to soil properties over a range of time scales, so that the soils of the future may not have the same infiltration properties as given in current datasets. These all have implications for the certainty, robustness and confidence of future recharge estimates.

If the likely consequences on groundwater systems of future change, resulting from both climate and socio-economic change, are to be assessed, it is advocated that hydrogeologists must increasingly work with researchers from other disciplines, such as socio-economists, agricultural modellers and soil scientists.

\section{References}

Alderwish A, Al-Eryani M (1999) An approach for assessing the vulnerability of the water resources of Yemen to climate change. Climate Research 12(2-3): 85-89

Ankeny MD, Kaspar TC, Prieksat MA (1995). Traffic effects on water infiltration in chisel plough and no-till systems. Soil Science of America Journal 59(1): 200-204

Argent RM (2004) An overview of model integration for environmental applicationscomponents, frameworks and semantics. Environmental Modelling \& Software 19(3), 219-234

Arnell NW (1998) Climate change and water resources in Britain. Climatic Change 39(1): 83-110 
Arnell A, Jenkins A, George DG (1994). The implication of climate change for the National Rivers Authority. National Rivers Authority R\&D Report 12, HMSO, London

Baron, JS Poff, NL Angermeier, PL Dahm, CN Gleick, PH Hairston, NG Jackson, RB Johnston, CA Richter, BD Steinman, AD (2002) Meeting ecological and societal needs for freshwater. Ecol. Appl 12(5), 1247-1260

Bobba AG (2002) Numerical modelling of salt-water intrusion due to human activities and sea-level change in the Godavari Delta, India. Hydrol. Sci. J.-J. Sci. Hydrol. 47: S67- S80

Boorman, DB, Hollis, JM, Lilly, A (1995) Hydrology of Soil Types: A Hydrologically based classification of the soils of the UK. Institute of Hydrology Report No. 126, Wallingford, UK.

Bowman RA, Nielsen DC, Vigil MF, Aiken RM (2000) Effects of sunflower on soil quality indicators and subsequent wheat yield. Soil Sci. 165(6): 516-522

Bragg, OM (2002) Hydrology of peat-forming wetlands in Scotland. Sci Total Envir 294(13), 111-129

Cannell MGR, Milne R, Hargreaves KJ, Brown TAW, Cruickshank MM, Bradley RI, Spencer T, Hope D, Billett MF, Adger WN, Subak S (1999) National inventories of terrestrial carbon sources and sinks: The UK experience. Clim. Change 42 (3): 505-530

Cannell RQ, Hawes JD (1994) Trends in tillage practices in relation to sustainable crop production with special reference to temperate climates. Soil Till. Res. 30: 245-282

Carter TR, Porter JH, Parry ML (1992) Some implications of climatic-change for agriculture in Europe. J. Exp. Bot. 43(253): 1159-1167

Cash DW, Moser SC (2000) Linking global and local scales: designing dynamic assessment and management processes. Global Environmental Change 10: 109-120

Chambers BJ, Garwood TWD (2000) Monitoring of water erosion on arable farms in England and Wales, 1990-1994. Soil Use \& Management 16(2): 93-99 
Chen CC, Gillig D, McCarl BA (2001) Effects of climatic change on a water dependent regional economy: A study of the Texas Edwards Aquifer. Clim. Change 49(4): 397-409

Chen ZH, Grasby SE, Osadetz KG (2002) Predicting average annual groundwater levels from climatic variables: an empirical model. J. Hydrol. 260(1-4): 102-117

Cooper DM, Wilkinson WB, Arnell NW (1995) The effects of climate changes on aquifer storage and river baseflow. Hydrol. Sci. J.-J. Sci. Hydrol. 40(5): 615-631

Conway D, Krol M, Alcamo J, Hulme M (1996) Future availability of water in Egypt: The interaction of global, regional, and basin scale driving forces in the Nile Basin. Ambio 25 (5): $336-342$

Croley TE, Luukkonen CL (2003) Potential effects of climate change on ground water in Lansing, Michigan. J. Am. Water Resour. Assoc. 39(1): 149-163

Danielopol, DL Griebler, C Gunatilaka, A Notenboom, J (2003) Present state and future prospects for groundwater ecosystems. Environ. Conserv. 30 (2); 104-130

Davies A, Shao J, Brignall P, Bardgett RD, Parry ML, Pollock CJ (1996) Specification of climatic sensitivity of forage maize to climate change. Grass Forage Sci. 51(3): 306-317

Easterling WE (1997) Why regional studies are needed in the development of fullscale integrated assessment modelling of global change processes. Global Environmental Change 7(4): 337-356

European Environment Agency (1998) Europe's Environment: The Second Assessment. Elsevier Science Ltd., Oxford

Feddema JJ, Freire S (2001) Soil degradation, global warming and climate impacts. Climate Research 17(2): 209-216

Gomez, E Ledoux, E Viennot, P Mignolet, C Benoit, M Bornerand, C Schott, C Mary, B Billen, G Ducharne, A Brunstein, D (2003). An integrated modelling tool for nitrates 
transport in a hydrological system: Application to the river Seine basin. Houille BlancheRev. Int. 3, 38-45

Harrison PA, Butterfield RE, (1996) Effects of climate change on Europe-wide winter wheat and sunflower productivity. Clim. Res. 7(3): 225- 241

Hernanz JL, Lopez R, Navarrete L, Sanchez-Giron V (2002) Long-term effects of tillage systems and rotations on soil structural stability and organic carbon stratification in semiarid central Spain. Soil Tillage Res. 66 (2): 129-141

Holman IP, Hiscock KM (1998) Land drainage and saline intrusion in the coastal marshes of northeast Norfolk. Quarterly Journal of Engineering Geology 31: 47-62

Holman, I.P., Hiscock, K.M. \& Chroston, P.N. (1999). Crag aquifer characteristics and water balance for the Thurne catchment, northeast Norfolk. Quarterly Journal of Engineering Geology, 32, 365-380

Holman IP, Loveland PJ, Najarro P (2001) 'Integrated Impacts on Water' in Holman, I.P. and Loveland, P.J. (eds.): 2001b. Regional Climate Change Impacts in East Anglia and the North West (the RegIS project). Final report of MAFF Project No. CC0337 (available from www.ukcip.org.uk)

Holman IP, Hollis JM, Bramley ME, Thompson TRE (2003) The contribution of soil structural degradation to catchment flooding: a preliminary investigation of the 2000 floods in England and Wales. Hydrology \& Earth System Sciences, 7(5), 754-765

Holman IP, Rounsevell MDA, Harrison PA, Nicholls RJ, Berry PM, Audsley E, Shackley S (2005a In Press) A regional, multi-sectoral and integrated assessment of the impacts of climate and socio-economic change in the UK: Part I Methodology. Climatic Change

Holman IP, Nicholls RJ, Berry PM, Harrison PA, Audsley E, Shackley S, Rounsevell MDA (2005b In Press) A regional, multi-sectoral and integrated assessment of the impacts of climate and socio-economic change in the UK: Part II Results. Climatic Change 
Hulme M, Jenkins GJ (1998) Climate Change Scenarios for the United Kingdom: Scientific Report. UK Climate Impacts Programme Technical Report No. 1, Climatic Research Unit, Norwich

IPCC- Intergovernmental Panel on Climate Change (2001) Climate Change 2001: Impacts, Adaptation and Vulnerability - Contribution of Working Group II to the Third Assessment Report of IPCC

Jones PD, Reid PA (2001) Assessing future changes in extreme precipitation over Britain using regional climate model integrations. Int. J. Climatol. 21(11): 1337-1356

Keating EH, Vesselinov VV, Kwicklis E, Lu ZM (2003) Coupling basin- and site-scale inverse models of the Espanola aquifer. Ground water 41 (2): 200-211

Kirshen PH, (2002) Potential impacts of global warming on groundwater in eastern Massachusetts. J. Water Resources Planning \& Management-ASCE 128(3): 216-226

Kort J, Collins M, Ditsch D (1998) A review of soil erosion potential associated with biomass crops. Biomass Bioenerg. 14(4): 351-359

Kruger A, Ulbrich U, Speth P (2001) Groundwater recharge in Northrhine-Westfalia predicted by a statistical model for greenhouse gas scenarios. Physics \& Chemistry Of The Earth Part B-Hydrology Oceans And Atmosphere 26(11-12): 853-861

Leemans R (1999) Modelling for species and habitats: new opportunities for problem solving. Science Of The Total Environment 240(1-3): 51-73

Loaiciga HA, Maidment DR, Valdes JB (2000) Climate-change impacts in a regional karst aquifer, Texas, USA. J. Hydrol. 227(1-4): 173-194

Loukas A, Vasiliades L, Dalezios NR (2002) Climatic impacts on the runoff generation processes in British Columbia, Canada. Hydrology \& Earth System Sciences 6(2): 211227 
Loveland PJ, Webb J (2003) Is there a critical level of organic matter in the agricultural soils of temperate regions: a review. Soil Tillage Res. 70(1): 1-18

Meigh JR, McKenzie AA, Sene KJ (1999) A grid-based approach to water scarcity estimates for eastern and southern Africa. Water Resources Management 13(2): 85-115

Nicholls RJ, Wilson T (2001) Integrated impacts on coastal areas and river flooding. In: Holman IP, Loveland PJ (eds.) Regional Climate Change Impacts in East Anglia and the North West (the RegIS project). Final report of MAFF Project No. CC0337 (available from www.ukcip.org.uk).

O'Leary GJ (1996) The effects of conservation tillage on potential groundwater recharge. Agricultural Water Management 31(1-2): 65-73

Parry ML, Hossell JE, Jones PJ, Rehman T, Tranter RB, Marsch JS, Rosenzweig C, Fischer G, Carson IG, Bunce RGH (1996) Integrating global and regional analyses of the effects of climate change: a case study of land use in England and Wales. Climatic Change 32: $185-198$

Parson EA, Granger Morgan M (2000) Chapter 3: Socioeconomic context for climate impact assessment. US National Assessment Synthesis Team Document. Public Comment Draft

Prudhomme C, Reynard N, Crooks S (2002) Downscaling of global climate models for flood frequency analysis: where are we now? Hydrol. Process. 16(6): 1137-1150

Pruski FF, Nearing MA (2002) Runoff and soil-loss responses to changes in precipitation: A computer simulation study. J. Soil Water Conserv. 57(1): 7-16

Quinn, NWT Brekke, LD Miller, NL Heinzer, T Hidalgo, H Dracup, JA (2004). Model integration for assessing future hydroclimate impacts on water resources, agricultural production and environmental quality in the San Joaquin Basin, California. Environ. Modell. Softw. 19(3), 305-316 
Reeves DW (1997). The role of soil organic matter in maintaining soil quality in continuous cropping systems. Soil \& Tillage Research 43(1-2): 131-167

Rounsevell MDA, Evans SP, Bullock P (1999) Climate change and agricultural soils: Impacts and adaptation. Climatic Change 43 (4): 683-709

Rounsevell MDA, Annetts JE, Audsley E, Mayr T, Reginster I (2003) Modelling the spatial distribution of agricultural land use at the regional scale. Agriculture, Ecosystems and Environment 95(2-3): 465-479

Shackley S, Deanwood R (2003) Constructing social futures for climate-change impacts and response studies: building qualitative and quantitative scenarios with the participation of stakeholders. Climate Research 24(1): 71-90

Sherif MM, Singh VP (1999) Effect of climate change on sea water intrusion in coastal aquifers. Hydrol. Process. 13(8): 1277-1287

Sophocleous M (2002) Interactions between groundwater and surface water: the state of science. Hydrogeology J. 10: 52-67

Stephens W, Hess TM, Knox J (2001) Review of the effects of energy crops on hydrology. Cranfield University report for Ministry of Agriculture, Fisheries and Food. Available from http://www.silsoe.cranfield.ac.uk/iwe/research/src.htm

Tebrugge F, During RA (1999) Reducing tillage intensity - a review of results from a longterm study in Germany. Soil Tillage Res. 53(1): 15-28

Tisdall JM, Oades JM (1982) Organic matter and water-stable aggregates in soil. J. Soil Sci. $33: 141-164$.

Voss R, May W, Roeckner E (2002) Enhanced resolution modelling study on anthropogenic climate change: Changes in extremes of the hydrological cycle. Int. J. Climatol. 22(7): $755-777$ 
Weatherhead EK, Knox JW (1999) Predicting and mapping the future demand for irrigation water in England and Wales. Agricultural Water Management 43: 203-218

Webb J. Loveland PJ, Chambers BJ, Mitchell R, Garwood T (2001) The impact of modern farming practices on soil fertility and quality in England and Wales. J. Agric. Sci. 137(2): $127-138$

Yusoff I, Hiscock KM, Conway D (2002) Simulation of the impacts of climate change on groundwater resources in eastern England. In: Hiscock KM, Rivett MO, Davidson RM (eds) Sustainable Groundwater Development. Geological Society, London, Special Publications, 193: 325-344

\section{Acknowledgements}

RegIS was funded by the Department of Environment, Food and Rural Affairs (Project No. CC0337) and the UK Water Industries Research within the UK Climate Impacts Programme. Contributions in kind were also provided by the Environment Agency and English Nature.

The contributions of the RegIS team members at Silsoe Research Institute, Environmental Change Institute (University of Oxford), Flood Hazard Research Centre (Middlesex University), Université Catholique de Louvain and University of Manchester are gratefully acknowledged. 


\section{Figures}

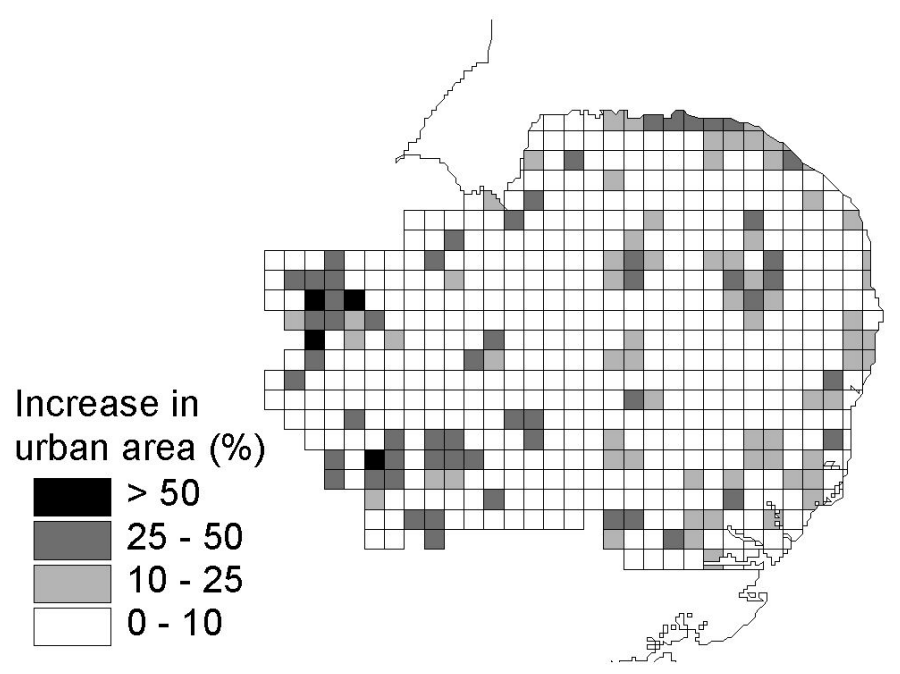

Figure 1: Example of the spatial socio-economic scenario parameters - percentage change in urban cover in East Anglia under the 2050s Regional Enterprise scenario

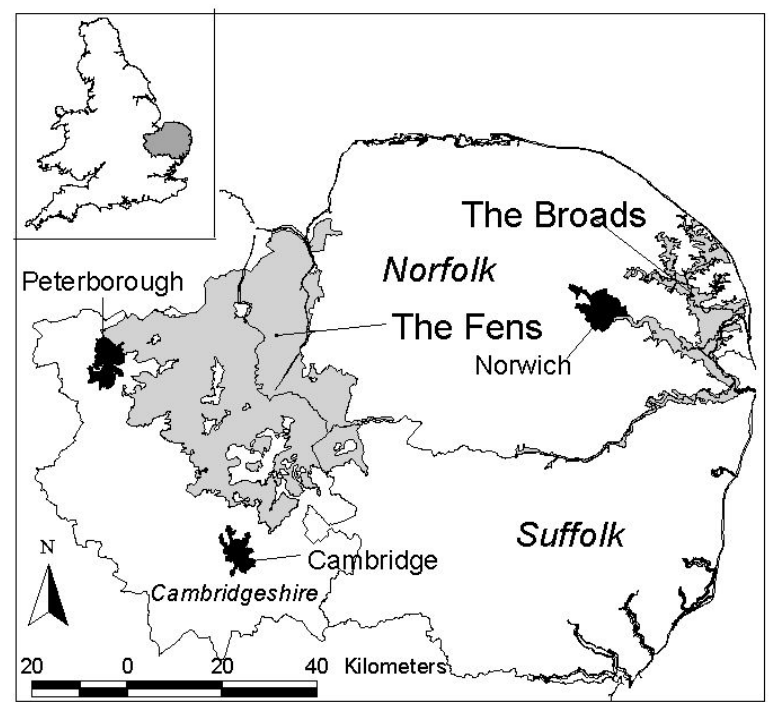

Figure 2: The East Anglian RegIS area 


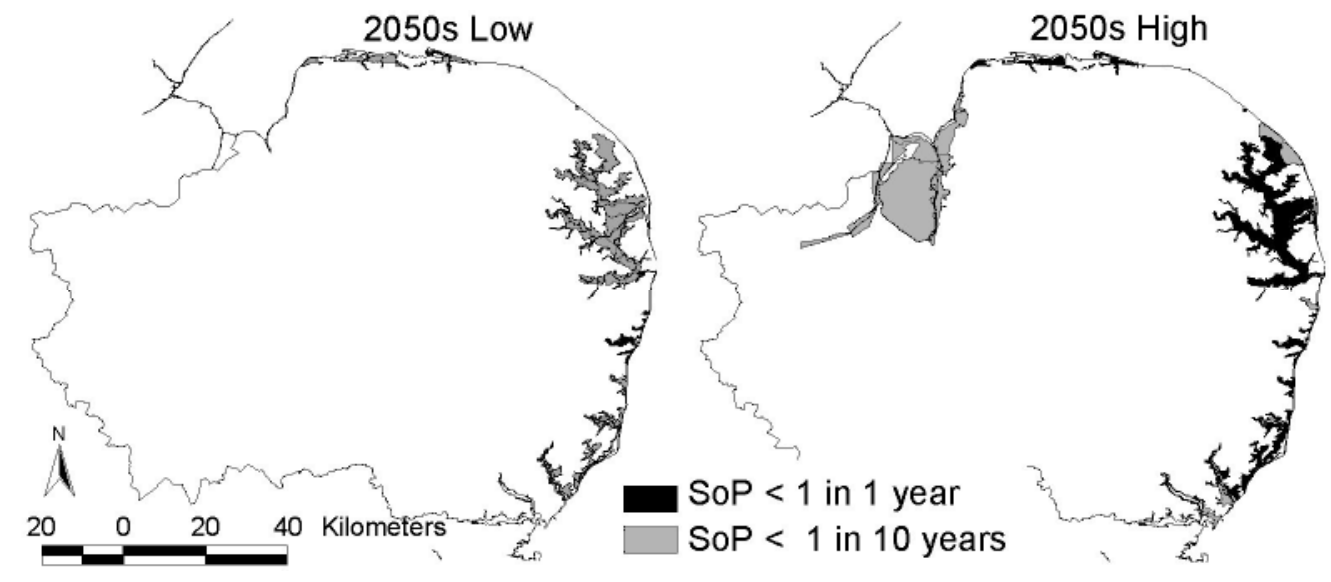

Figure 3: Flood compartments in East Anglia with a future standard of protection (SoP) of $<1$ in 10 years and $<1$ in 1 year under the 2050s Low and High scenarios (adapted from Nicholls and Wilson, 2001)

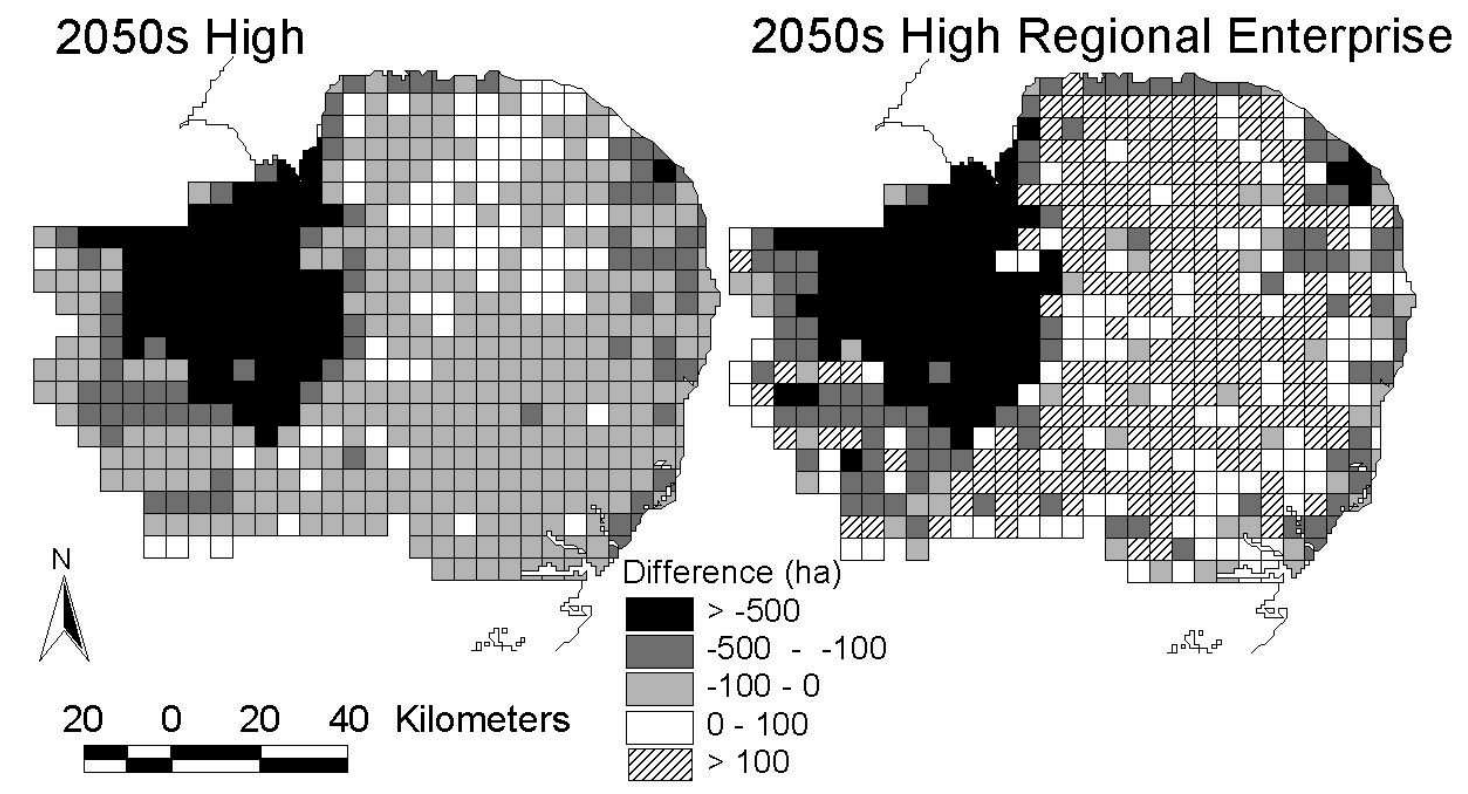

Figure 4: Difference in area (ha) of cereal crops between the baseline 1995 scenario and (left) the 2050s High (climate only) scenario and (right) the 2050s High Regional Enterprise scenario 


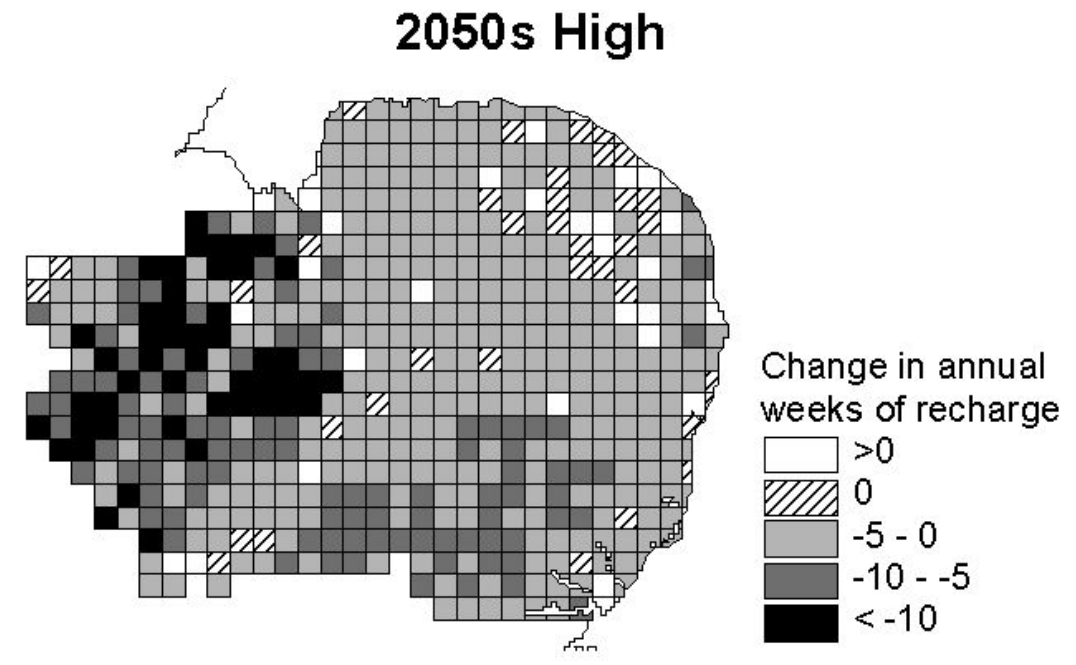

Figure 5: Change in the average annual potential recharge period (compared to the Baseline) in the 2050s High climate change scenario
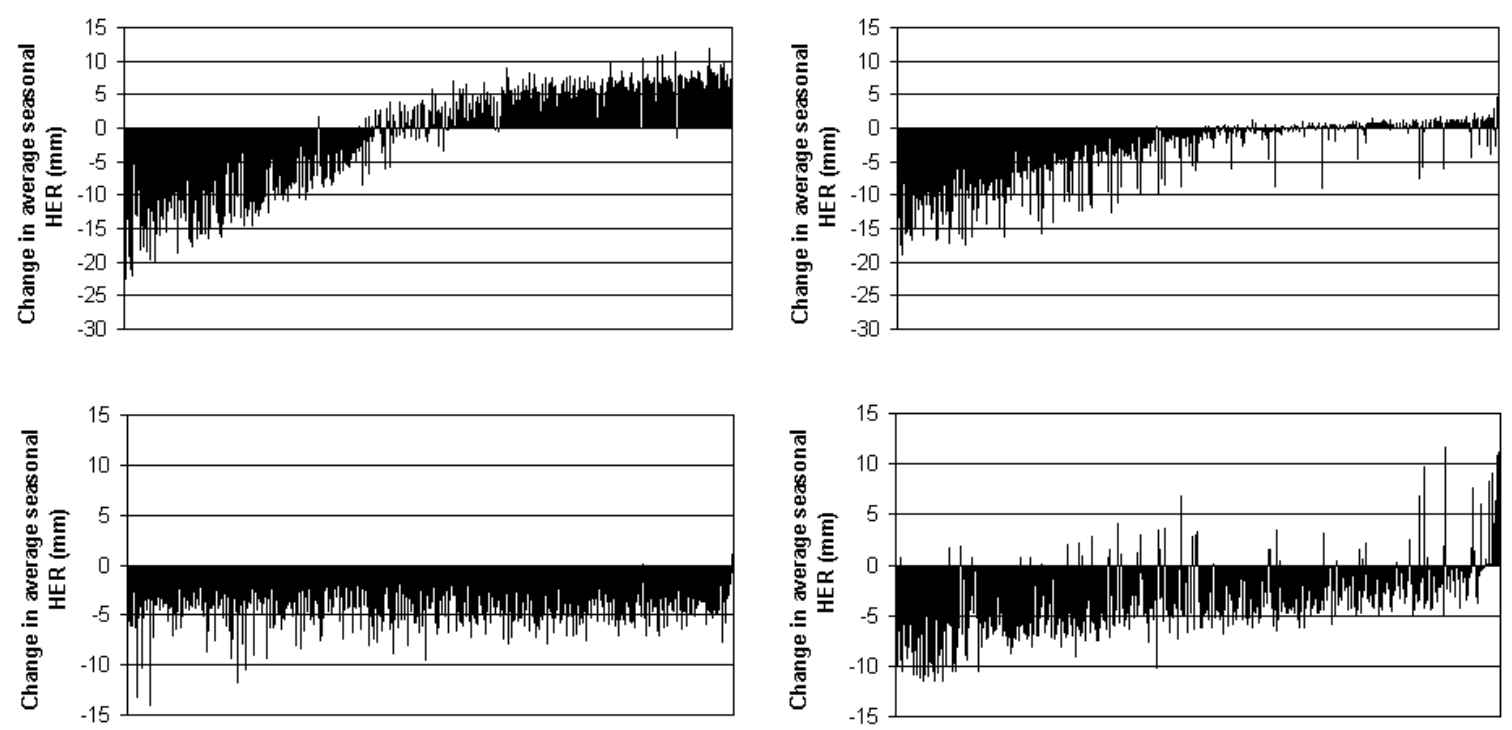

Figure 6: Seasonal changes in HER under a 2050s High with baseline socio-economic scenario future, with grid squares ranked by their change in annual HER: (top left) winter; (top right) spring; (bottom left) summer and (bottom right (autumn) 
Climate scenario effect only

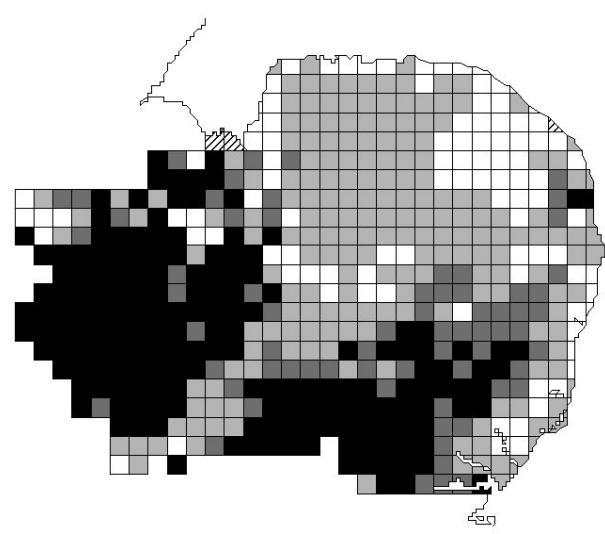

Socio-economic (Regional Enterprise) scenario effect only

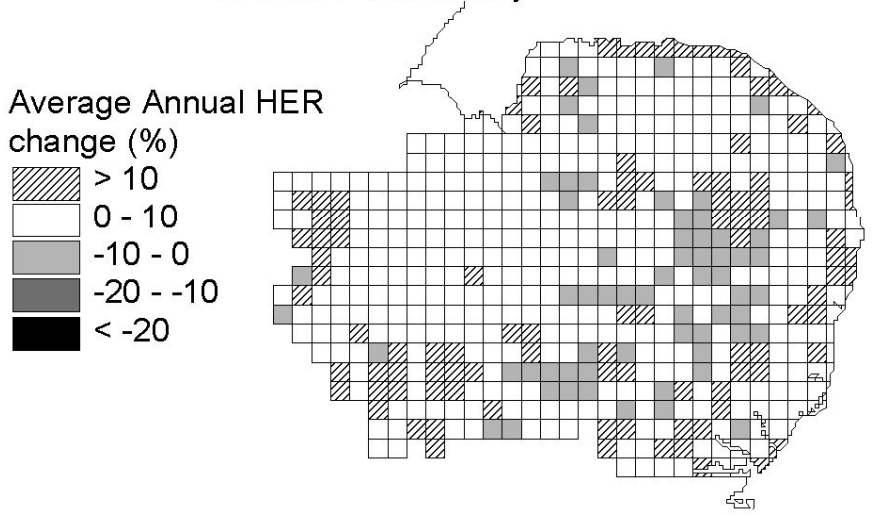

Figure 7: Contribution to the percentage change (compared to the baseline) in average annual Hydrologically Effective Rainfall in East Anglia under 2050s High Regional Enterprise future from the climate and the socio-economic scenarios 